\title{
SOME ENGINEERING FACTORS THAT CONTROL GROUNDWATER LEVEL
}

\author{
M. N. El Awady', S. A. Tayel², A. A. El Meseery ${ }^{3}$, \\ S. H. Dosoky ${ }^{4}$ and A. M. Mousa ${ }^{5}$
}

\begin{abstract}
\end{abstract}
The purpose of this investigation to study some engineering factors that control groundwater level. Also, to study variations in water table depths with time in different soils and amendments to accommodate variant crops and periods in growing season. To achieve this goal, two experiments were carried out, namely: (1) a laboratory experiment by using the soil tank model and (2) a field experiment, including utilization of rice straw as drain filling material. Three control depths were used for drainage outflow in the soil tank model, namely: (20, 12 and $4 \mathrm{~cm}$ from soil surface). The soil surface in the soil tank model was watered by surface irrigation, followed by draining through drains and was measured water table level at different times. The results obtained from model could be summarized as follows: Water table falling rate at midpoint between drains increases with the drainage depth and decreases with drain-spacing for both of soil with and without of rice straw. Water table falling rate at mid-point between drains in sandy loam soil with drain of straw was much more than bare soil. Water table falling rate at mid-point between drains in sandy soil with drain of straw was less than bare soil. Water table falling rate at mid-point between drains in clay loam soil with two drains of straw was more than one drain. Three treatments of soil were used in the field experiment, namely: silty clay soil, silty clay soil with drain of rice straw and silty clay soil with two drains of rice straw. Two control depths were used for drainage outflow, namely: 70 and $40 \mathrm{~cm}$ from soil surface. Two spaces for drains were used as follows: 3 m (by opened the two drains),

\footnotetext{
1. Prof. of Agric. Eng., Fac. of Agric., Ain Shams Univ.

2. Prof. of Agric. Eng., Fac. of Agric. Eng., Al-Azhar Univ.

3. Prof. of Agric. Eng., Fac. of Agric. Eng., Al-Azhar Univ.

4. Assis. Prof. of Agric. Eng., Fac. of Agric. Eng., Al-Azhar Univ.

5. Assis. Lec. of Agric. Eng., Fac. of Agric. Eng., Al-Azhar Univ.
} 
$8 \mathrm{~m}$ (by closed one of drains during drainage). Results have demonstrated that: Water table falling rate at mid-point between drains increases with the drainage depth and decreases with drain-spacing for both of soil with and without of rice straw. Water table falling rate at mid-point between drains in silty clay soil with two drains of straw was more than one drain and one drain was more than bare soil. Also, it has been got relations correlate between water table heights and time at different engineering designs for subsurface drainage system with different soils, with and without rice straw, by dimensional analysis.

\section{INTRODUCTION}

The drains are most of the time of subsurface design at depths suitable for root crops, in addition to other safety factors. All

these lead to a lot of losses of irrigation water and fertilizers, and lead to the pollution of ground and drainage water. Also, some studies recommended that the maximum intensity provided by drains is not usually needed at all times during the growing season. So there is opportunity to reduce drainage rates during some periods. Also some results indicated that there will not be demand for deeper drainage at all periods of the growing season (Wahba, 2002). Thus, most countries started in practicing new systems. There will be a demand for the integrated design and management of irrigation and drainage systems, to control drainage in groundwater depths. In North Carolina, controlled drainage has been included in the best management practices and is now applied to more than 270,000 ha; participating farmers receive $75 \%$ of the predetermined average cost of installation when implementing this practice (Evans and Skaggs, 2004). El-Atfy (2000) mentioned that farmers are inclined to block the collector drain pipes at the nearest manhole with whatever is available, i.e. mud and straw within the rice fields to reduce the losses. It was necessary to modify the layout and the design of the drainage system and the concept of a modified layout has been developed in the rice growing areas. The modified layout consists of a main collector drain with several sub-collector area remained unchanged as they are still based on the growing conditions of the most critical "dry- foot" crop (cotton). Each sub-collector coincides with one 
crop consolidation unit and is equipped, at the junction with the main collector, with a closing device to regulate the sub-collector outflow.

Bonaiti and Borin (2010) mentioned that, the implementation of simple devices for controlling drainage allows excess water to be retained in the soil for some days, with a dramatic reduction in water discharged and nitrate-nitrogen lost. In fact, controlled drainage and subirrigation reduced total measured drainage flow by $77 \%$ and total nitrate-nitrogen losses by $70 \%$ when applied to subsurface drains drainage systems (treatment S-CI). In the open ditches drainage systems (treatment O-CI) controlled drainage and subirrigation reduced total measured drainage and total nitrate-nitrogen losses by 47 and 72\%, respectively. Ayars et al. (2006) showed that a drain depth will be specified and the spacing will be calculated based on the recharge schedule and the mid-point water table depth criteria. Subsequently, the drain depth will be varied to calculate a range of depths and spacing for an economic analysis. The most economic drain depth and spacing is then selected from analyses of several drain system configurations. The USBR recommends installation of drains at a depth of $2.4 \mathrm{~m}$, if possible, to provide a balance between the system cost and spacing. Deep placement of the drains generally results in a wide drain spacing that lowers the system cost relative to shallow and therefore more closely spaced drains. However, in many cases deep placement has been shown to result in an excessive salt load being discharged with the drainage water. Shallow drain placement will result in shallower flow paths and in areas with increasing salt with depth in the soil profile will result in lower salt concentrations in the drainage water and reduced loads. Muirhead et al. (1996) said that in wellstructured soils with deep water tables, excess water in the root zone quickly drains to the subsoil after irrigation or rainfall, and water logging is transient. However, the irrigated clay soils in the Murray-Darling Basin are poorly structured and do not have sufficient macro pores for rapid drainage. Water logging in these soils results from low subsoil permeability causing perched water tables, as well as high groundwater tables. Cultivation, particularly when the soil is wet, compacts and smears the soil and so destroys the few macro pores which are able to conduct and drain excess water. High water tables not only 
maintain a high soil water content in the layers at risk of compaction, but also reduce the capacity of the subsoil to accept water draining from the root zone. Yang et al. (2010) investigated the effects of residual rice straw cutting height on paddy soil fertility. The average amount of rice straw residue for different cutting heights were $1,420 \mathrm{~kg} / \mathrm{ha}$ at $10 \mathrm{~cm}$, $1,850 \mathrm{~kg} / \mathrm{ha}$ at $15 \mathrm{~cm}, 2,400 \mathrm{~kg} / \mathrm{ha}$ at $20 \mathrm{~cm}$. Among the soil physical properties, soil hardness and bulk density were decreased and porosity was increased with rice straw retention. Organic matter, available silicate content, and cation exchange capacity were dramatically decreased when rice straw was collected.

The major aim of this research is to study some engineering factors that control groundwater level. The study also includes the utilization of rice straw in filling the drainage gaps.

\section{MATERIALS AND METHODS}

Two experiments were carried out, namely: (1) a laboratory experiment by using the soil tank model and (2) a field experiment, including utilization of rice straw as drain filling material.

\section{The laboratory experimental:}

The experiment was carried out at "Irrigation Laboratory, Agricultural Engineering Faculty, Al - Azhar University" during year of 2014. The soil tank model was made of plexi-glass with thickness $5 \mathrm{~mm}$. The inside length, width and depth of the soil tank were 60,10 and $55 \mathrm{~cm}$, respectively. The detailed description of the model is shown in Fig. 1. Two tiles of perforated polyvinyl chloride (PVC) were used as drains and were covered by cloth and enveloped by gravel filter. Two drains were connected with water table control device, consisting of a horizontal junction and riser to control water table level. Six treatments of soil, namely: (1) sandy loam, (2) sandy loam with drain of rice straw, (3) sandy, (4) sandy with drain of rice straw, (5) clay loam with drain of rice straw and (6) clay loam with two drains of rice straw were used with two spaces for drains, namely: (1) $30 \mathrm{~cm}$ (by opening the two drains) and (2) by assumption it is, $80 \mathrm{~cm}$ (by closing one of the drains and setting an observation well at $10 \mathrm{~cm}$ spacing from that drain) as in Fig.2. Three control depths were used for drainage outflow $(20,12$ and $4 \mathrm{~cm}$ from soil 
surface). Observation wells were installed in the soil tank model at equal spacing to monitor the water table level.

1. 1. Soil mechanical analysis and $K_{\mathbf{s}}$ : Mechanical analysis for soils and $\mathrm{K}_{\mathrm{s}}$ were carried out at the "Laboratory of Soil and Water Department, Faculty of Agriculture, Al-Azhar University" as follows:

Table 3.1: Mechanical analysis and saturated hydraulic conductivity "Ks" of the studied soil samples from soils of practical experiments.

\begin{tabular}{|c|c|c|c|c|}
\hline \multicolumn{3}{|c|}{ Particle size distribution \% } & \multirow{2}{*}{$\begin{array}{c}\text { Textural } \\
\text { class }\end{array}$} & $\begin{array}{c}\mathrm{K}_{\mathrm{s}} \\
(\mathrm{cm} / \mathrm{h})\end{array}$ \\
\cline { 1 - 2 } Clay & Silt & Sand & Clay loam & 2.8 \\
\hline 40 & 18 & 42 & Sandy loam & 4.5 \\
\hline 16 & 14 & 70 & Sandy & 7.5 \\
\hline \multicolumn{2}{|c|}{4.47} & $\begin{array}{c}54.49 \text { (fine) } \\
40.74 \text { (coarse) }\end{array}$ & & \\
\hline
\end{tabular}

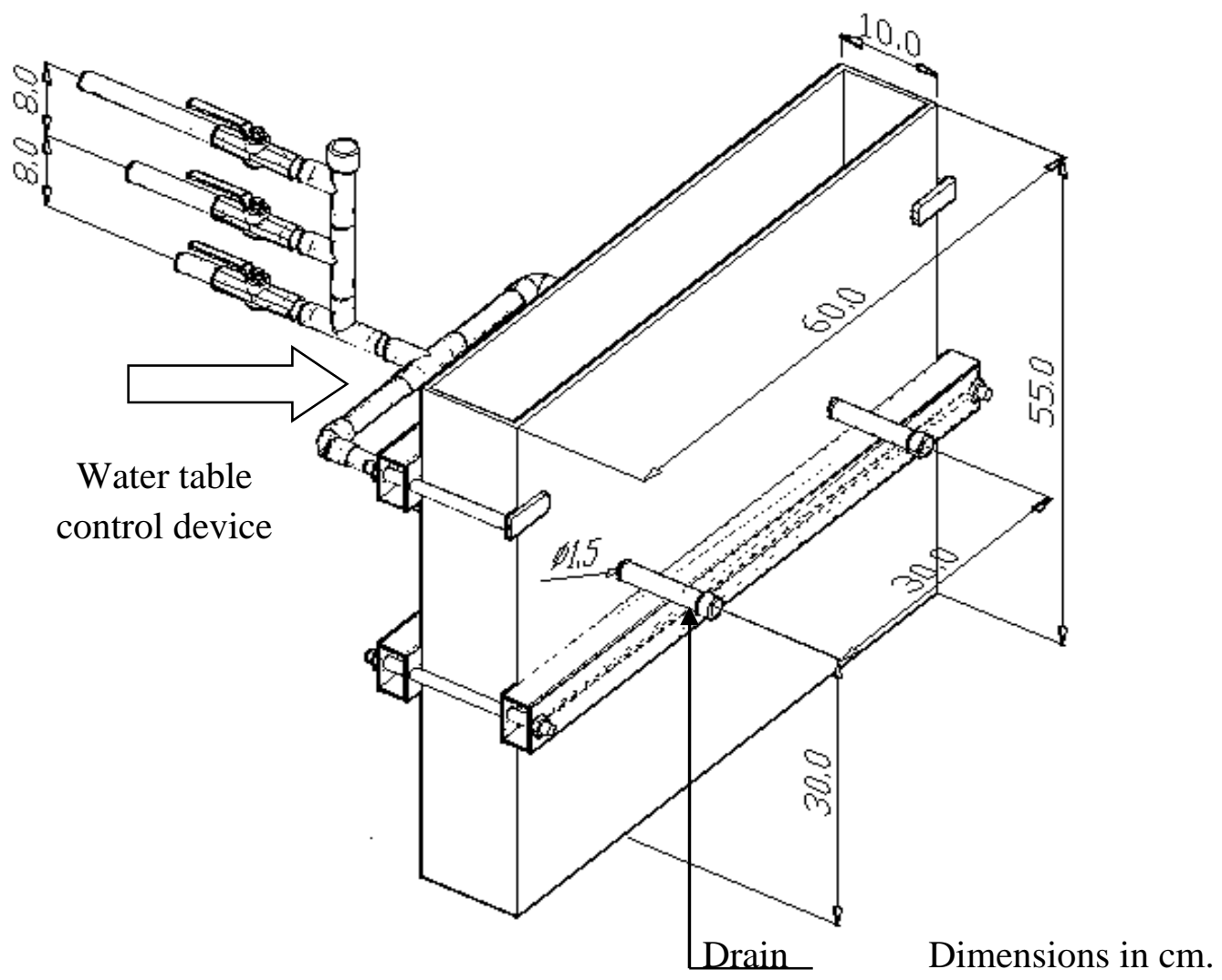

Fig. 1: Isometric of the soil tank model with two drains and water table control device. 


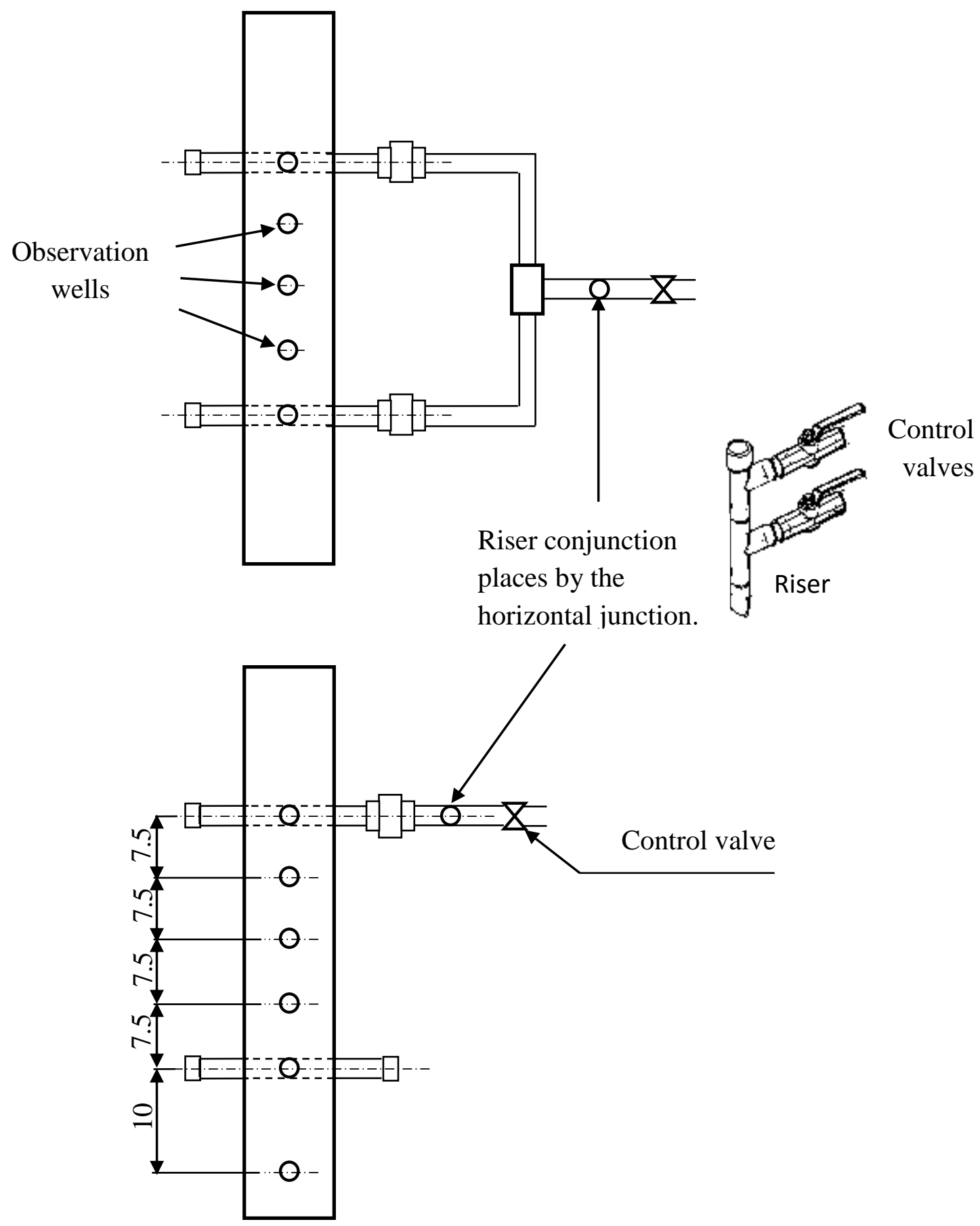

Fig. 2: Two plan views for the soil tank model in states of outflow from two drains and one drain to change drain-spacing. 


\subsection{Agricultural residues as fillers for drain conduits (rice straw):}

The ground rice straw was used in two treatments as in Fig. 3. In the first treatment, rice straw was laid beneath the soil surface with $2 \mathrm{~cm}$ thickness and high at the same drains depth in the form of a perpendicular drain to drains from two sides. The second treatment, rice straw was added in the same as before with the addition of another drain of rice straw at $12 \mathrm{~cm}$ depth from the soil surface with $2 \mathrm{~cm}$ thickness and high along the model. The first treatment was used with the three types of soil and the second treatment was used with clay loam only.
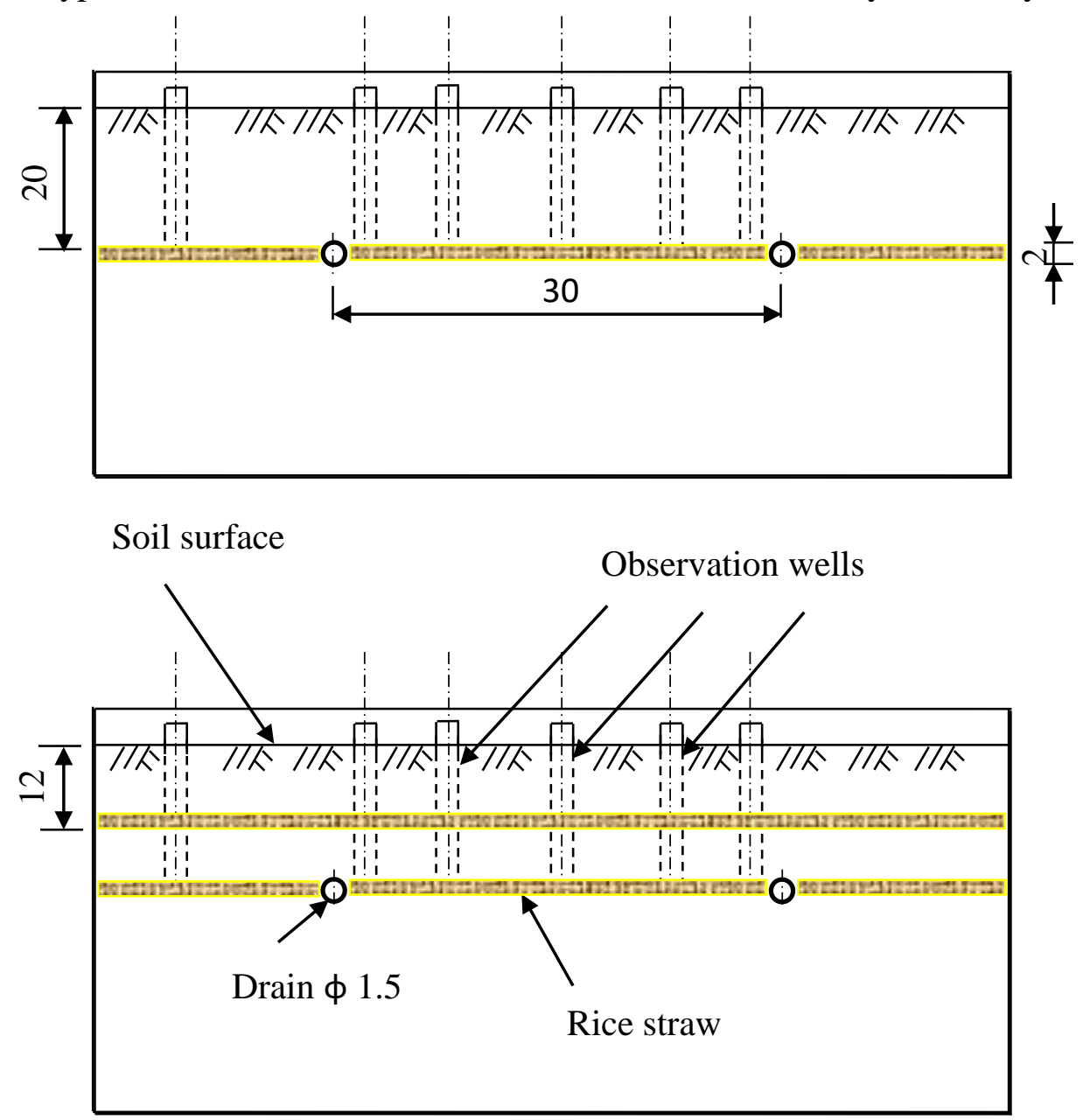

Dimensions in $\mathrm{cm}$.

Fig. 3: Two cross sections in the soil tank model to show addition ways of rice straw in the form of drain and two drains. 
1. 3. Measurement apparatus for water table level: To measure the water table drawdown during the drain flow, graduated tubes for distance $20 \mathrm{~cm}$ were made of plastic as in Fig. 4. A float from foam was stuck with tubes ends to move with free water moving surface during drainage operations inside observation wells to monitor the water table level.

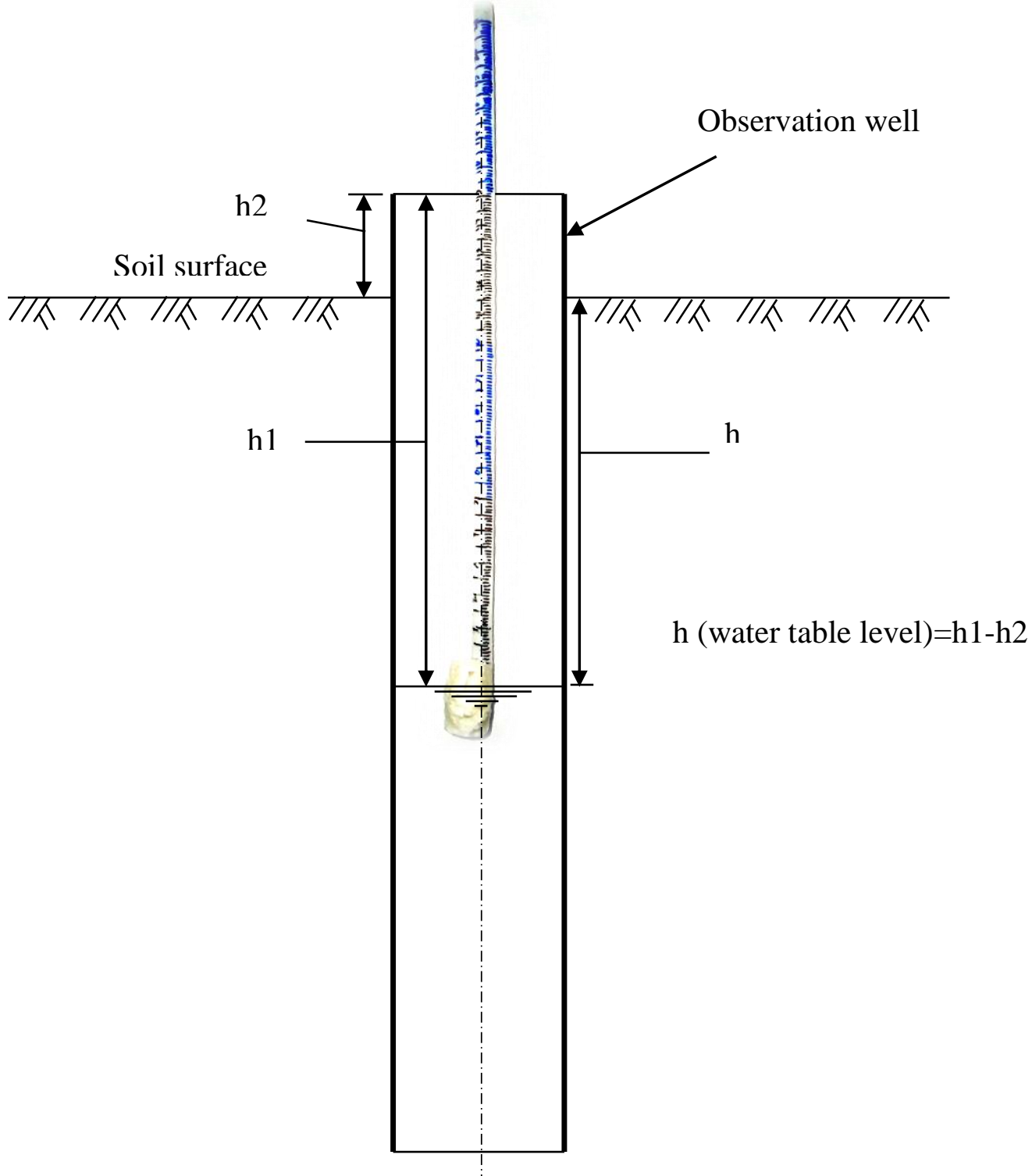

Fig. 4: Graduated tube inlet observation well to measure water table level. 
1. 4. Irrigation water application: The soil surface in the soil tank model was watered by surface irrigation, followed by draining through drains, and this procedure was repeated one more time, to check the success of the drainage operation. Then, the soil was saturated with water until the water table reached below soil surface by about 3-5 mm approximately, whereas the plugs were closed. After establishing water table, the drains were opened at the desired depth.

\section{The field experiment:}

\section{1. Experimental site and treatments:}

The field study was carried out at Belbeis, Sharkia (بليس،الثرقية) during 2015 in silty clay soil. The plot was divided into three subplots as in Figs. 5, 6 and 7. In the first subplot, the drains were installed without adding rice straw. In the second subplot, the drains were installed with adding drain of rice straw of width of $20 \mathrm{~cm}$ and $10 \mathrm{~cm}$ height at the same drain depth perpendicular to the two sides. In the third subplot, the drains were installed with rice straw as in the previous subplot but with adding another drain of rice straw at $30 \mathrm{~cm}$ depth from the soil surface and at a width of $20 \mathrm{~cm}$, and $10 \mathrm{~cm}$ height along the subplot. Subplot was $100 \mathrm{~cm}$ wide and $600 \mathrm{~cm}$ long. Subplot contained 2 subsurface tile drains $(5 \mathrm{~cm}$ in diameter) spaced at $300 \mathrm{~cm}$ between tiles at an average drain depth of $70 \mathrm{~cm}$ below the soil surface. The average slope of the tile was $2 \%$. Each drain (100 cm long) had 270 longitudinal perforations, $0.02 \mathrm{~cm}$ width and $4.4 \mathrm{~cm}$ long. Each drain was connected with a riser attached to two outlets, which were at 70 and $40 \mathrm{~cm}$ depths from soil surface. The two outlets were connected with a P.V.C tube $25 \mathrm{~cm}$ diameter as a manhole to control water table by valves and a combination of outflow water to estimate the discharge as in Fig. 8. Observation wells were installed in the soil with inner diameter of $5 \mathrm{~cm}$ and perforated as in drain tubes and made of (P.V.C as drains). An auger was used to make holes in soil to set observation wells to monitor the water table level. Observation wells were installed as in Figs. 5, 6 and 7 on equal spacings of about $75 \mathrm{~cm}$, except at the end well which was at $100 \mathrm{~cm}$ from drain to discharge for $800 \mathrm{~cm}$ drain spacing.

\section{2. Soil:}

The samples of soil were collected at 30 to $50 \mathrm{~cm}$ depths from field. 


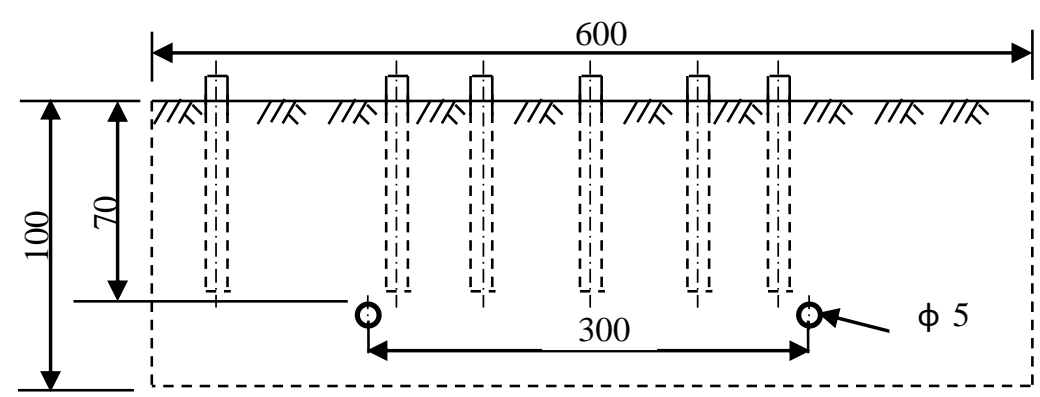

Section elevation At A-A without addition straw.

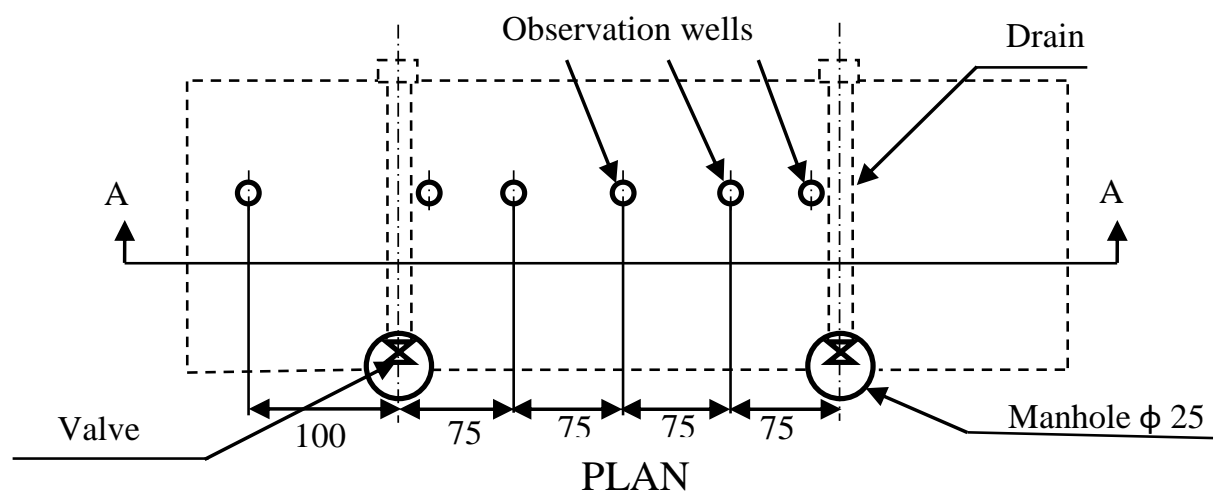

Fig. 5: Plan and section elevation for drainage control system without addition of rice straw in silty clay soil.

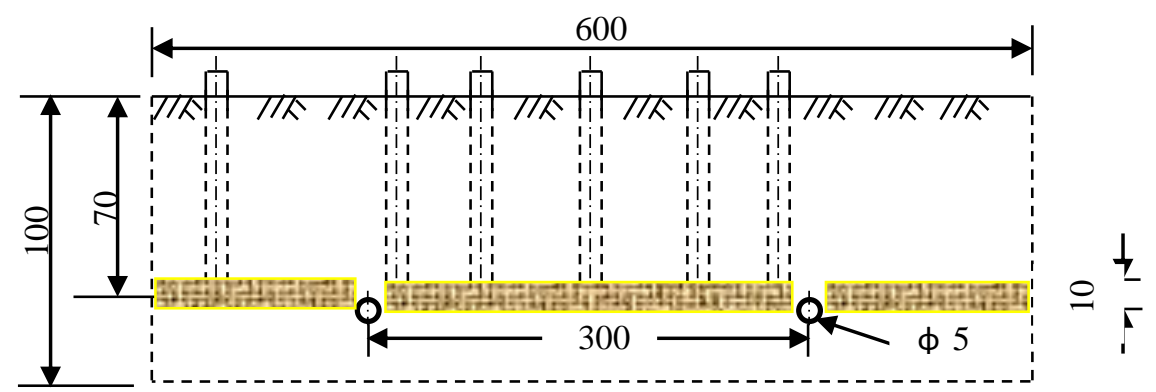

Section elevation At A-A with addition drain of straw.

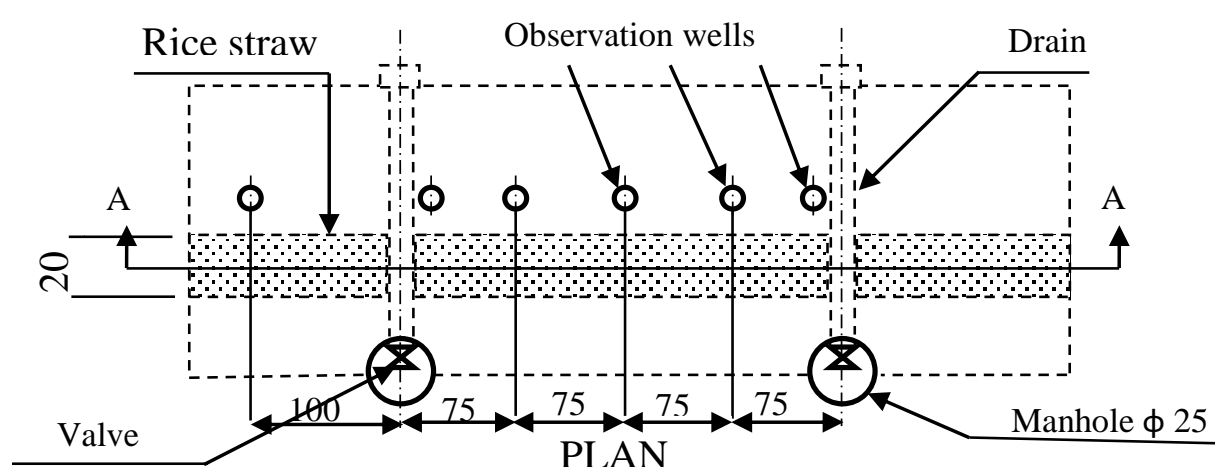

Dimensions in $\mathrm{cm}$.

Fig. 6: Plan and section elevation for drainage control system with addition of drain of rice straw in silty clay soil. 


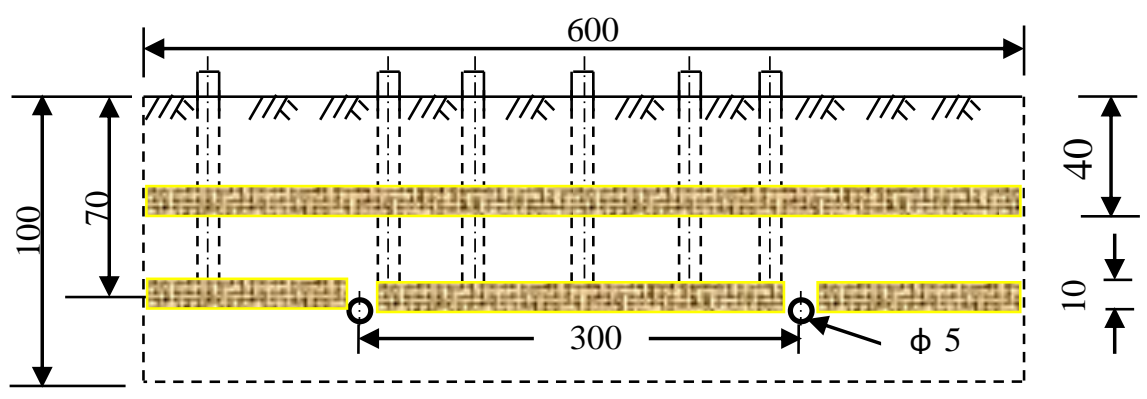

Section elevation At A-A with addition two drains of straw.

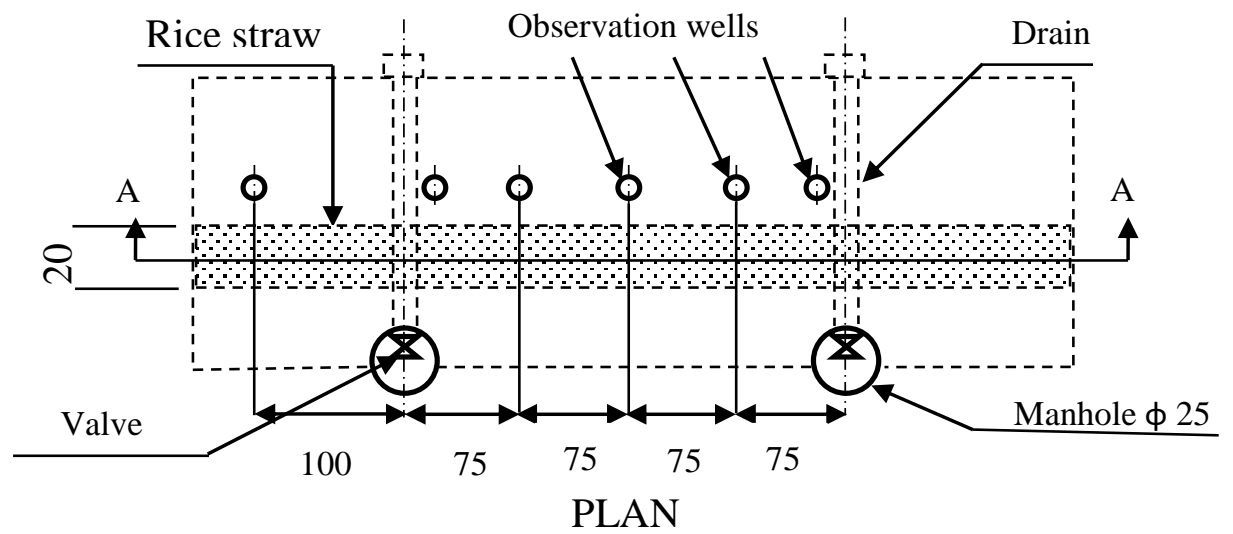

Fig. 7: Plan and section elevation for drainage control system with addition of two drains of rice straw in silty clay soil.

Soil surface

Manhole $\Phi 25$

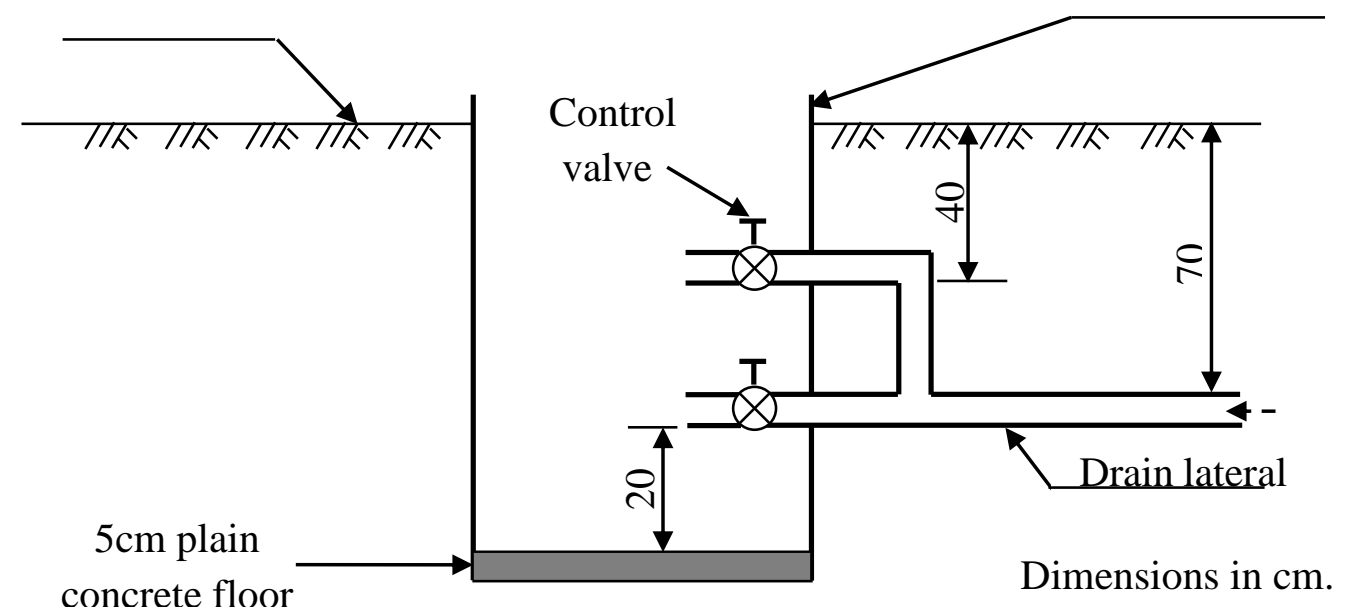

Fig. 8: A controlled water-table depth system via a manhole. 
Mechanical analysis and $\mathrm{K}_{\mathrm{s}}$ were made at Reclamation and Development Center Desert Soils, Faculty of Agriculture, Cairo University as follows:

Table 2: Mechanical analysis and saturated hydraulic conductivity " $K_{s}$ " of the studied soil sample from soil of field experiments.

\begin{tabular}{|c|c|c|c|c|}
\hline \multicolumn{3}{|c|}{ Particle size distribution \% } & Textural class & $\begin{array}{c}\mathrm{K}_{\mathrm{s}} \\
(\mathrm{cm} / \mathrm{h})\end{array}$ \\
\hline Clay & Silt & Sand & & 1.15 \\
\hline 44.5 & 40.2 & 15.3 & Silty clay & 1.2 \\
\hline
\end{tabular}

\section{3. Rice straw placement:}

Rice straw was placed in two subplots as in Figs. 6 and 7. In the second subplot, rice straw was laid below soil surface at a width of $20 \mathrm{~cm}$ and $10 \mathrm{~cm}$ height at the same drains depth perpendicular to drains from two sides. In the third subplot, rice straw was added in the same previous way with the addition of another layer of rice straw at $40 \mathrm{~cm}$ depth from soil surface and at a width of $20 \mathrm{~cm}, 10 \mathrm{~cm}$ height along the subplot.

\section{4. Irrigation water application:}

The soil surface was watered by surface irrigation with drains closed. The soil was filled up by water until below soil surface with an average of approximately $5 \mathrm{~cm}$. After establishing water table, the drains were opened at the desired depth.

\section{5. Measurement of water table level:}

Water table level was measured by a steel tape set into the observation well from water surface up to the well edge. The readings were taken at predetermined times to estimate water table depths (by subtracting of observation well height above soil surface from the tape reading Fig. 4).

\section{Dimensional analysis for variables:}

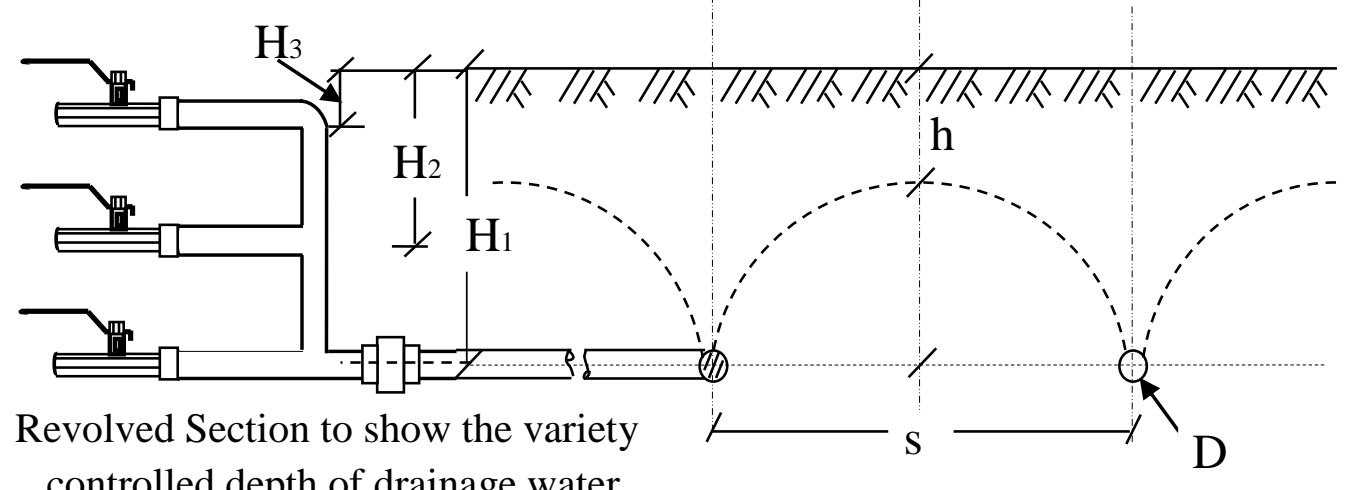

controlled depth of drainage water. 
$\mathrm{h}=\mathrm{f}(\mathrm{s}, \mathrm{H}, \mathrm{t}, \mathrm{g}, \mathrm{D}, \mathrm{k})$

Where:

$\mathrm{h}=$ water table falling under soil surface at mid-point between drains (L).

$\mathrm{s}=$ drain-spacing $(\mathrm{L})$.

$\mathrm{H}=$ the outlet depth of drainage water which vary from $\mathrm{H}_{1}$ to $\mathrm{H}_{3}(\mathrm{~L})$.

$\mathrm{t}=$ time of water table falling for different levels at mid-point between drains (T).

$\mathrm{g}=$ the acceleration of gravity $\left(\mathrm{L} / \mathrm{T}^{2}\right)$.

$\mathrm{D}=$ drain diameter $(\mathrm{L})$.

$\mathrm{k}=$ hydraulic conductivity of the soil $(\mathrm{L} / \mathrm{T})$.

By using the Buckingham Pi theory, we get the following groups:

$\pi_{1}=\mathrm{h} / \mathrm{H}$, termed as "water table height" parameter.

$\pi_{2}=\mathrm{t} . \mathrm{k} / \mathrm{s}$, termed as "time" parameter.

$\pi_{3}=\mathrm{D} / \mathrm{s}$, termed as "hydraulic design" parameter.

$\pi_{4}=\mathrm{H} / \mathrm{s}$, termed as "engineering design" parameter.

$\pi_{5}=\mathrm{k} /(\mathrm{g} . \mathrm{s})^{0.5}$, termed as "soil permeability" parameter.

The functional relation is as follows:

$\mathrm{h} / \mathrm{H}=\mathrm{f}(\mathrm{t} . \mathrm{k} / \mathrm{s}, \mathrm{H} / \mathrm{s}$ ) ........ (1) (with $\pi 3$ and $\pi 5$ are constant).

Experiments were conducted to determine the characteristic functions and constants.

\section{Laboratory experiments:}

\section{RESULTS AND DISCUSSION}

\subsection{Water table variation for sandy loam soil (without and with drain of rice straw):}

Results indicated that water table falling rate at mid-point between drains increases with the drainage depth and decreases with drain-spacing for both of sandy loam soil with and without drain of straw, except for drainage depths of 20 and $12 \mathrm{~cm}$ for sandy loam soil with drain of straw where rate increased with drain-spacing.

This may be due to that the absorbed water from rice straw increases with time, then loss it when moisture content decrease in soil. However, water table falling rate at mid-point between drains in sandy loam soil with drain of straw was much more than bare soil, as shown in Fig. 9.

These results are expected because hydraulic head is higher at deeper drainage. Also, with increasing drain-spacing there will be big soil 


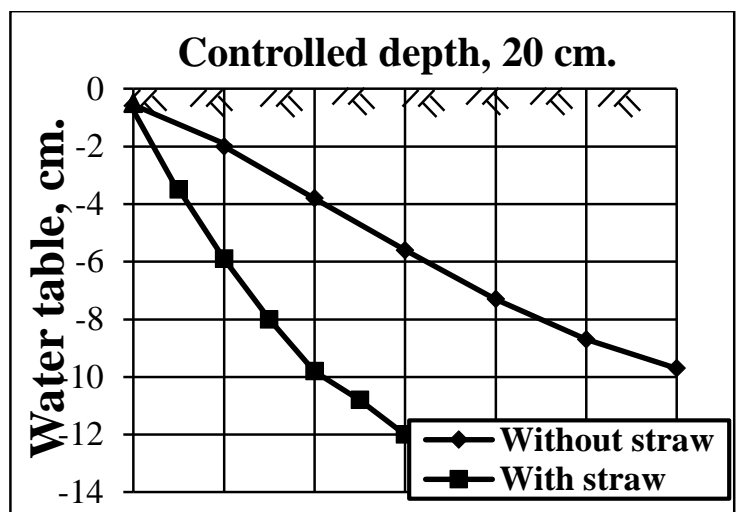

IRRIGATION AND DRAINAGE

Controlled depth, $20 \mathrm{~cm}$.
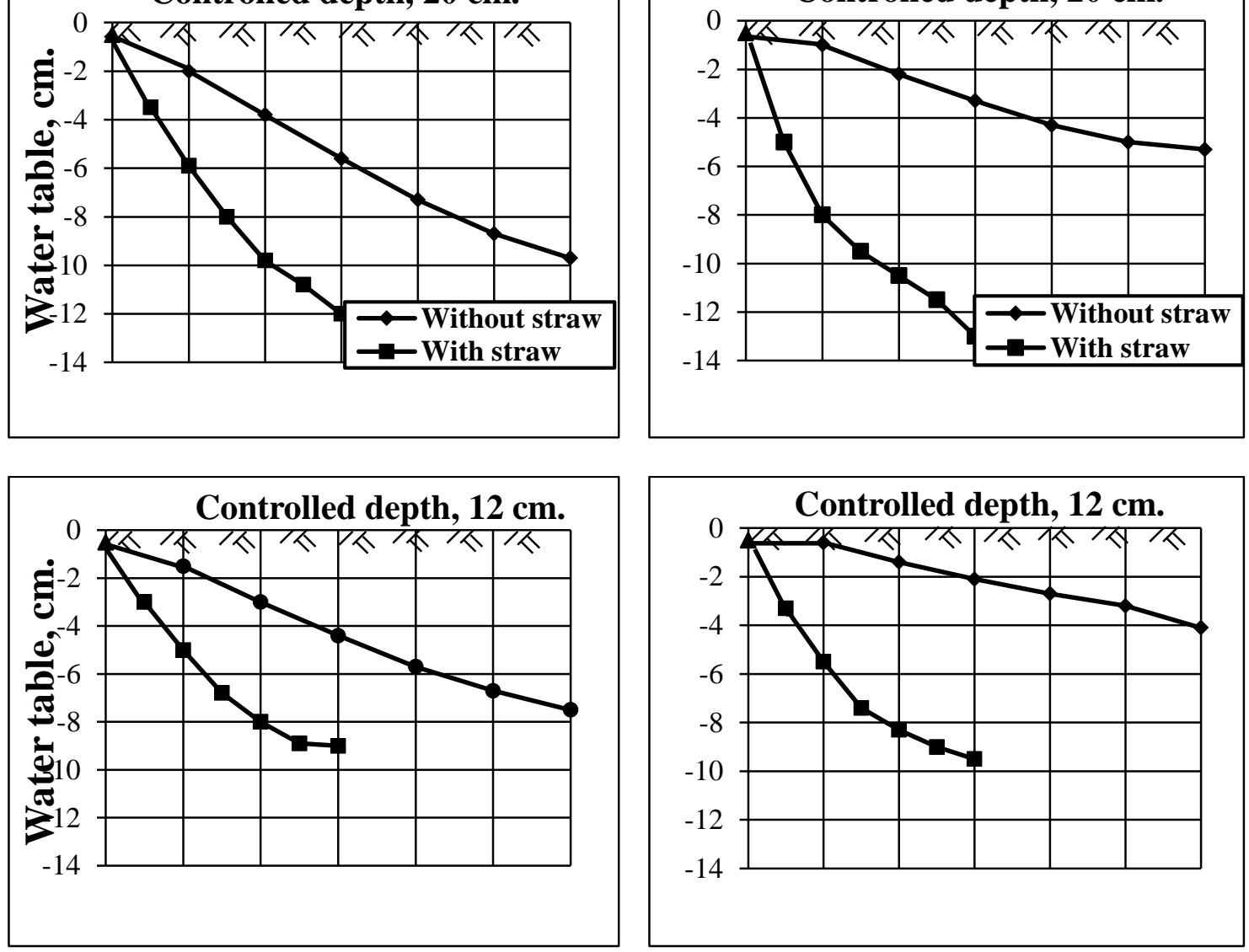

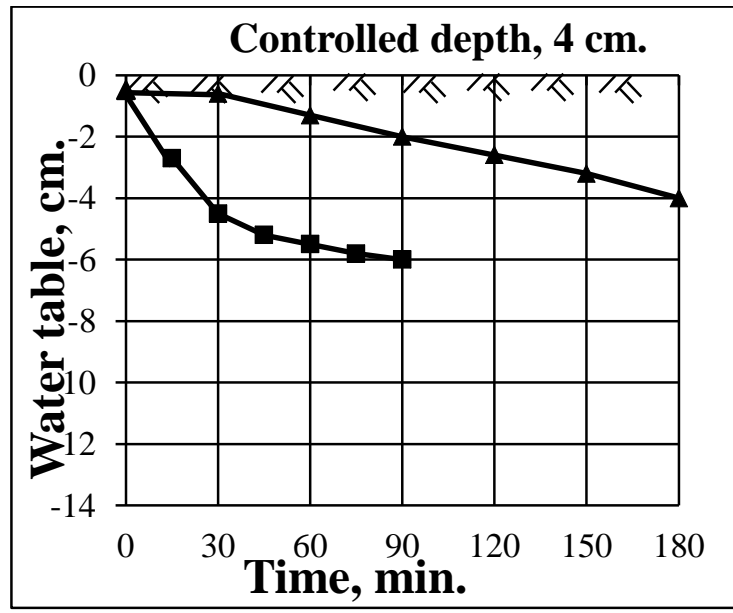

Distance from drain, $15 \mathrm{~cm}$.

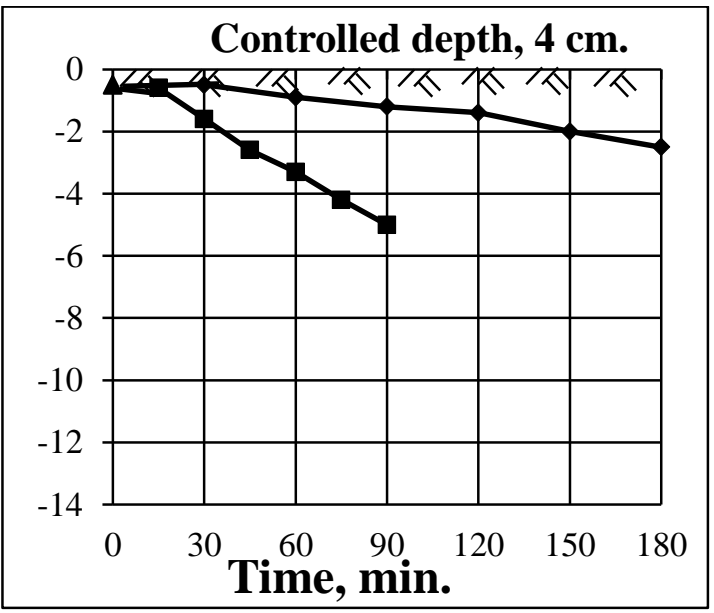

Distance from drain, $40 \mathrm{~cm}$.

Fig. 9: Variations in water table depth with time at 15 and $40 \mathrm{~cm}$ distances from drain with 20,12 and $4 \mathrm{~cm}$ controlled depths for sandy loam soil without and with drain of rice straw. 
volume drained. Meanwhile rice straw improved water percolation and acted as another perpendicular drain.

\subsection{Water table variation for sandy soil (without and with drain of rice straw):}

Results indicated that water table falling rate at mid-point between drains increases with drainage depth and decreases with drain-spacing for both of sandy soil with and without drain of straw except, drainage depth of $4 \mathrm{~cm}$ where rate increased with drain-spacing.

This may be due to that the controlled depth of $4 \mathrm{~cm}$ is very near from soil surface which lead to increasing capillary rise, and decreasing hydraulic head. These factors were much affected drain-spacing lesser. However, water table falling rate at mid-point between drains in sandy soil with drain of straw was less than bare soil as shown in Fig. 10. This may be due to the addition of the ground rice straw which leads to decreasing of water percolation towards drains in sandy soil.

\subsection{Water table variation for clay loam soil (with one and two drains of rice straw):}

Results indicated that water table falling rate at mid-point between drains increases with drainage depth, except drain-spacing of $30 \mathrm{~cm}$ for clay loam soil with two drains of straw where the $20 \mathrm{~cm}$ depth was less than the $12 \mathrm{~cm}$ depth. This may be due to the presence another drain of straw at the level of $12 \mathrm{~cm}$ of soil surface, which leaded to substitution rapidly for water when drainage water outlet rise to $12 \mathrm{~cm}$ depth.

Also, water table falling rate at mid-point between drains decreases with drain-spacing for both of clay loam soil with drain and two drains of straw, except drainage depth of $4 \mathrm{~cm}$ for clay loam soil with drain of straw where rate increased with drain-spacing. However, water table falling rate at mid-point between drains in clay loam soil with two drains of straw was more than with one drain as shown in Fig. 11. These results are expected because addition of another drain of rice straw above drain leads to increasing of water percolation in clay loam soil.

\section{Field experiment:}

- Water table variation for silty clay soil (without and with one and two drains of rice straw):

Results indicated that water table falling rate at mid-point between drains 

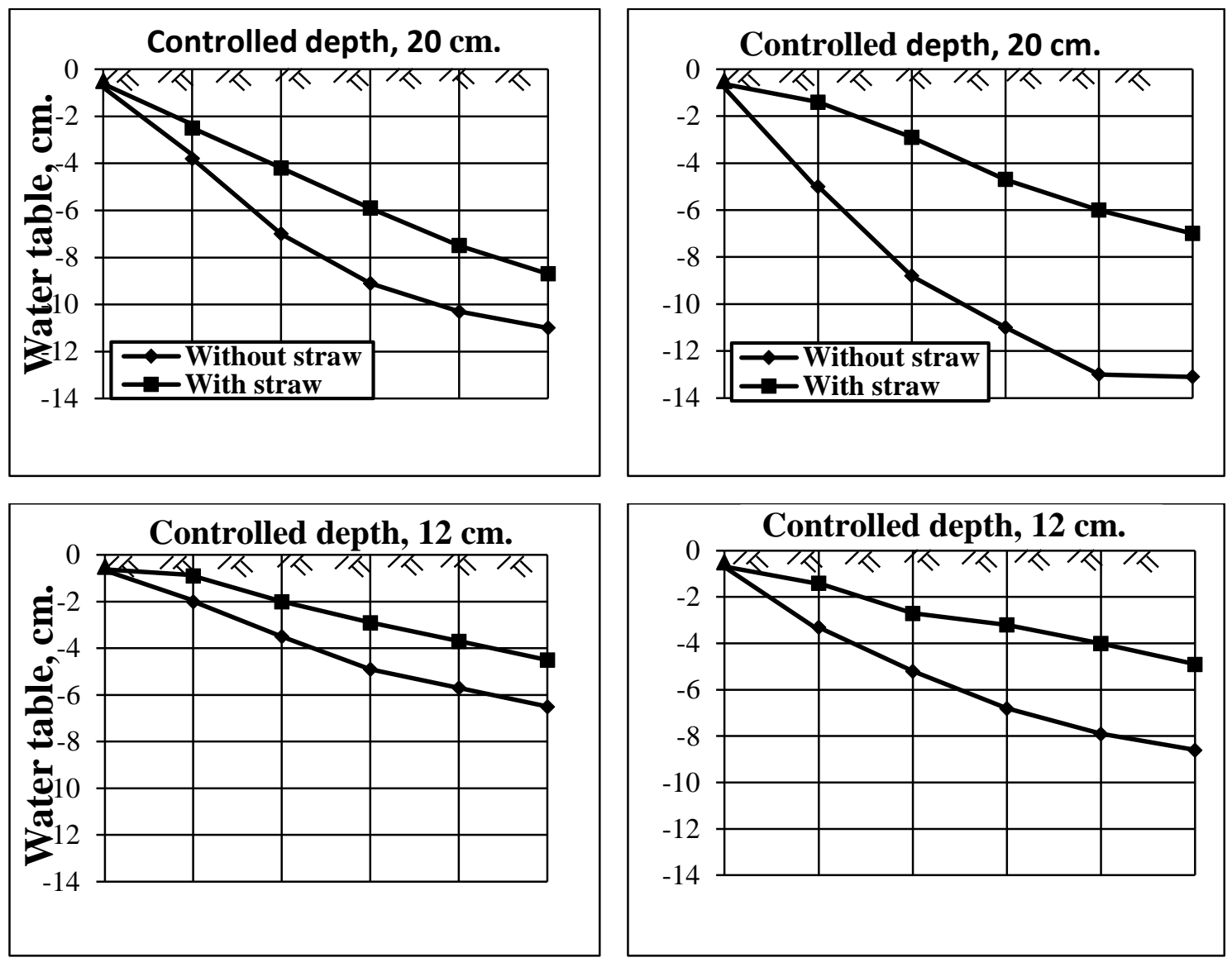

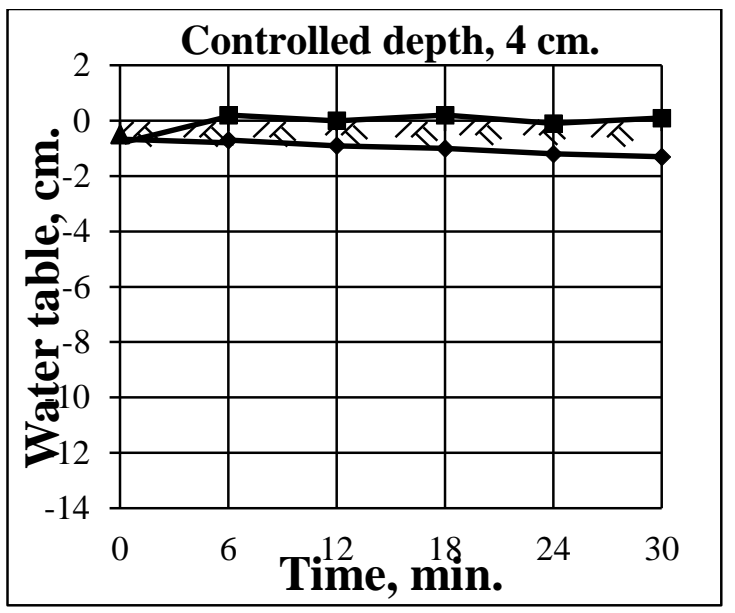

Distance from drain, $15 \mathrm{~cm}$.

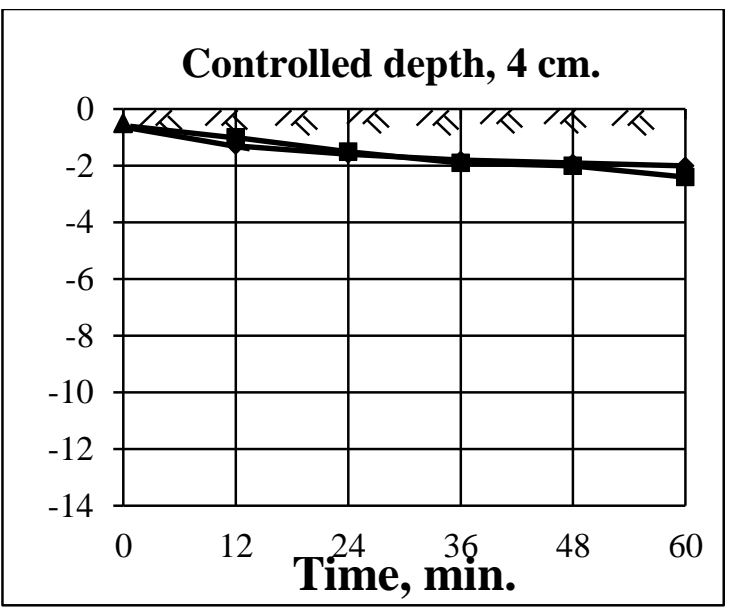

Distance from drain, $40 \mathrm{~cm}$.

Fig. 10: Variations in water table depth with time at 15 and $40 \mathrm{~cm}$ distances from drain with 20,12 and $4 \mathrm{~cm}$ controlled depths for sandy soil without and with drain of rice straw. 


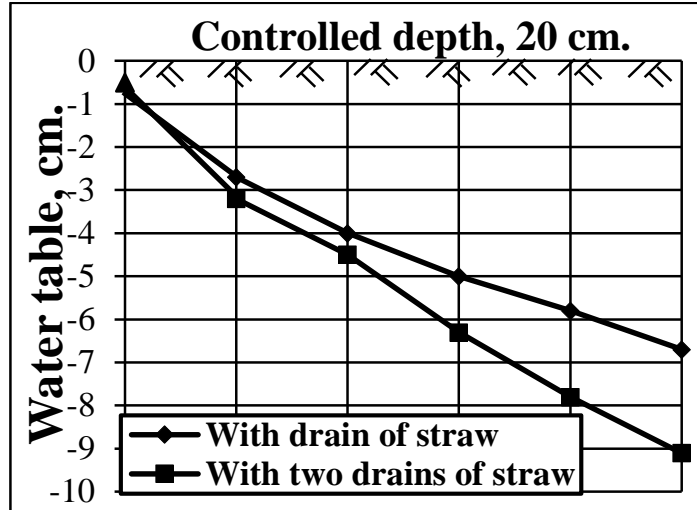

Controlled depth, $20 \mathrm{~cm}$.
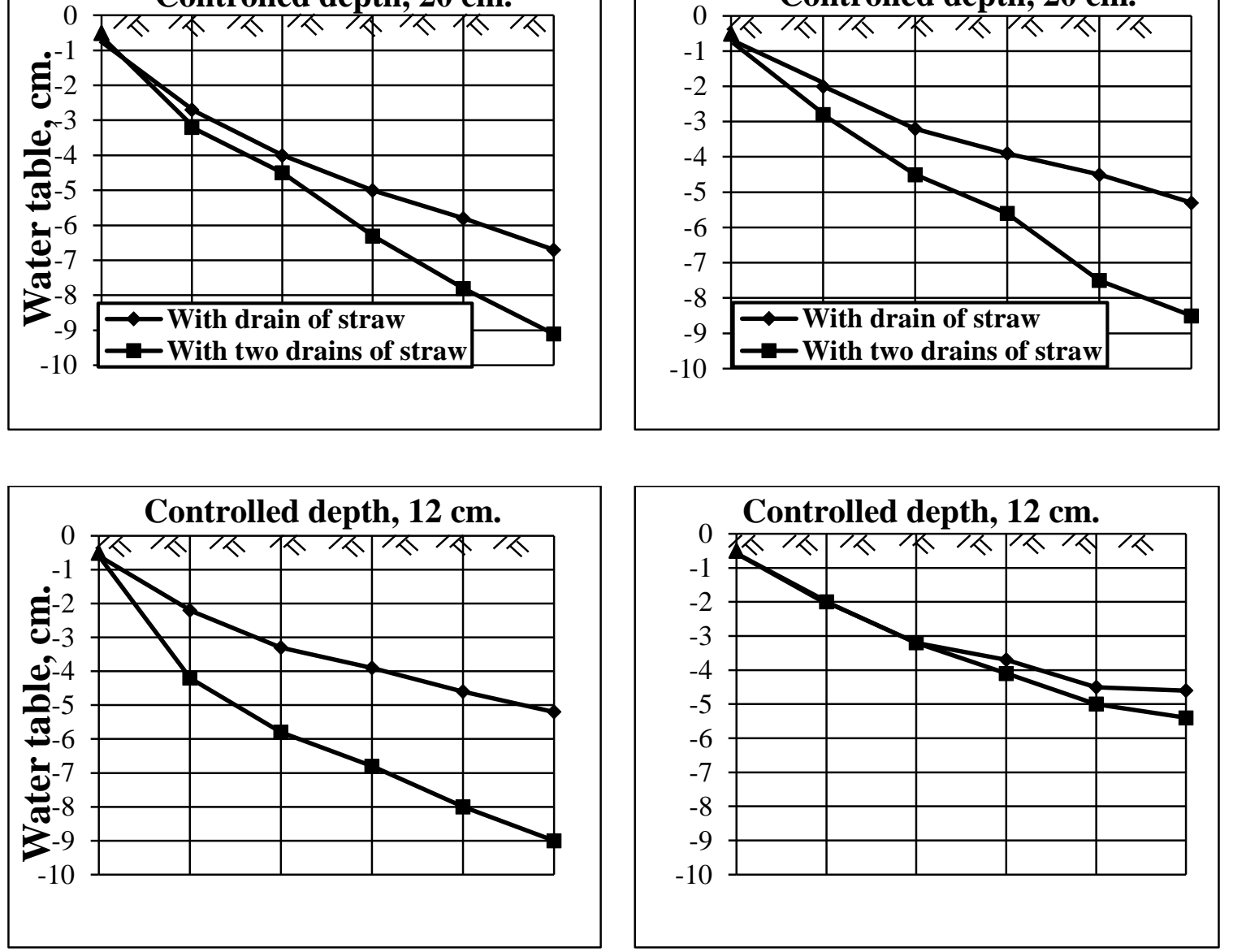

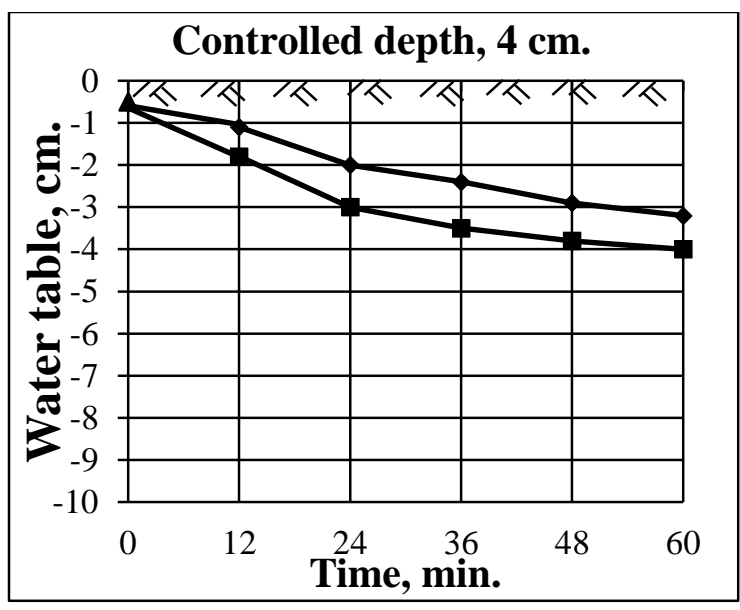

Distance from drain, $15 \mathrm{~cm}$.

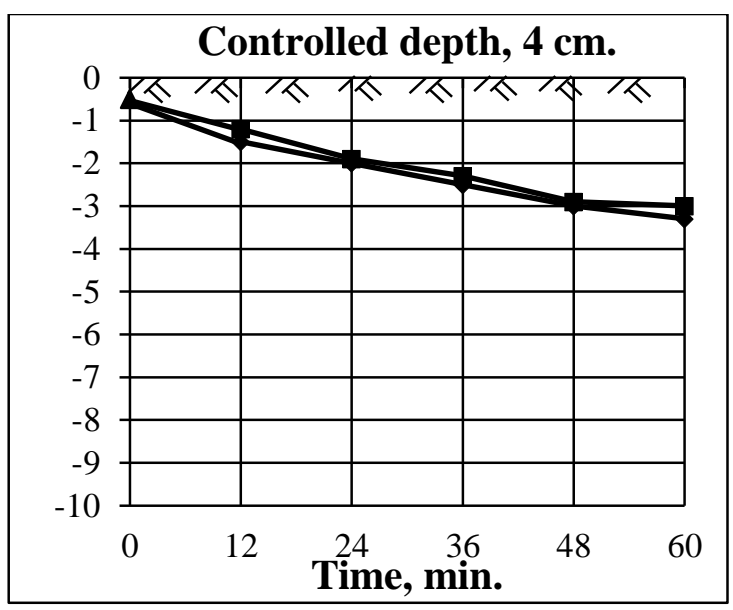

Distance from drain, $40 \mathrm{~cm}$.

Fig. 11: Variations in water table depth with time at 15 and $40 \mathrm{~cm}$ distances from drain with 20, 12 and $4 \mathrm{~cm}$ controlled depths for clay loam soil with one and two drains of rice straw. 
increases with drainage depth for all the treatments, except drain-spacing of $800 \mathrm{~cm}$ for silty clay soil with one drain of straw where rate decreased. Also, results indicated that water table falling rate decreases with drainspacing for all the treatments, except drainage depth of $40 \mathrm{~cm}$ for silty clay soil with one and two drains of straw where it increased. This may be due to that the absorbed water from rice straw increases with time, then loss it through adjacent areas. That was apparent at $40 \mathrm{~cm}$ depth because, with $40 \mathrm{~cm}$ drainage depth added irrigation water by quantities more than $70 \mathrm{~cm}$ drainage depth to raise water through riser.

However, water table falling rate at mid-point between drains in silty clay soil with two drains of straw was more than one drain, and one drain was more than bare soil as shown in Fig. 12.

\section{Dimensional analysis for variables:}

Data obtained from the experiments were used in the correlation of water table height: $\pi_{1}=\mathrm{h} / \mathrm{H}$ to time: $\pi_{2}=\mathrm{t} . \mathrm{k} / \mathrm{s}$, at different engineering design: $\pi_{4}=\mathrm{H} / \mathrm{s}$, with hydraulic design: $\pi_{3}=\mathrm{D} / \mathrm{s}$ and soil permeability: $\pi_{5}=$ $\mathrm{k} /(\mathrm{g} . \mathrm{s})^{0.5}$ are constant in the following functional relation: $\mathrm{h} / \mathrm{H}=\mathrm{f}(\mathrm{t} . \mathrm{k} / \mathrm{s}, \mathrm{H} / \mathrm{s}) \quad$ ( as mentioned previously)

The relation between $\pi_{1}$ and $\pi_{2}$ determined at different $\pi_{4}$ with $\pi_{3}$ and $\pi_{5}$ are constant. The parameters "a" and "b" depend on values $\pi_{4}$ and therefore, the relations between groups were founded as follows:

\section{- The laboratory experiment:}

\section{1- Sandy loam soil:}

$\mathrm{h}=\mathrm{t} . \mathrm{k}(\mathrm{H} / \mathrm{s})(1.84-\mathrm{H} / \mathrm{s})$

\section{2- Sandy soil:}

$\mathrm{h}=2.86 \mathrm{t} . \mathrm{k}(\mathrm{H} / \mathrm{s})^{0.6}+0.13 \mathrm{H}$

3- Sandy loam soil with drain of rice straw:

$\mathrm{h}=1.71 \mathrm{t} . \mathrm{k}(\mathrm{H} / \mathrm{s})^{0.18}-0.21 \mathrm{H}^{2} / \mathrm{s}+0.22 \mathrm{H}$

4- Sandy soil with drain of rice straw:

$\mathrm{h}=2.55 \mathrm{t} . \mathrm{k}(\mathrm{H} / \mathrm{s})^{0.76}+0.015 \mathrm{H}$

5- Clay loam with drain of rice straw:

$\mathrm{h}=1.82 \mathrm{t} . \mathrm{k}(\mathrm{H} / \mathrm{s})^{0.24}+0.08 \mathrm{H}$

6- Clay loam with two drains of rice straw:

$\mathrm{h}=-13.3 \mathrm{t} . \mathrm{k}(\mathrm{H} / \mathrm{s})^{2}+12.32 \mathrm{t} . \mathrm{k}(\mathrm{H} / \mathrm{s})+0.1 \mathrm{H}$ 

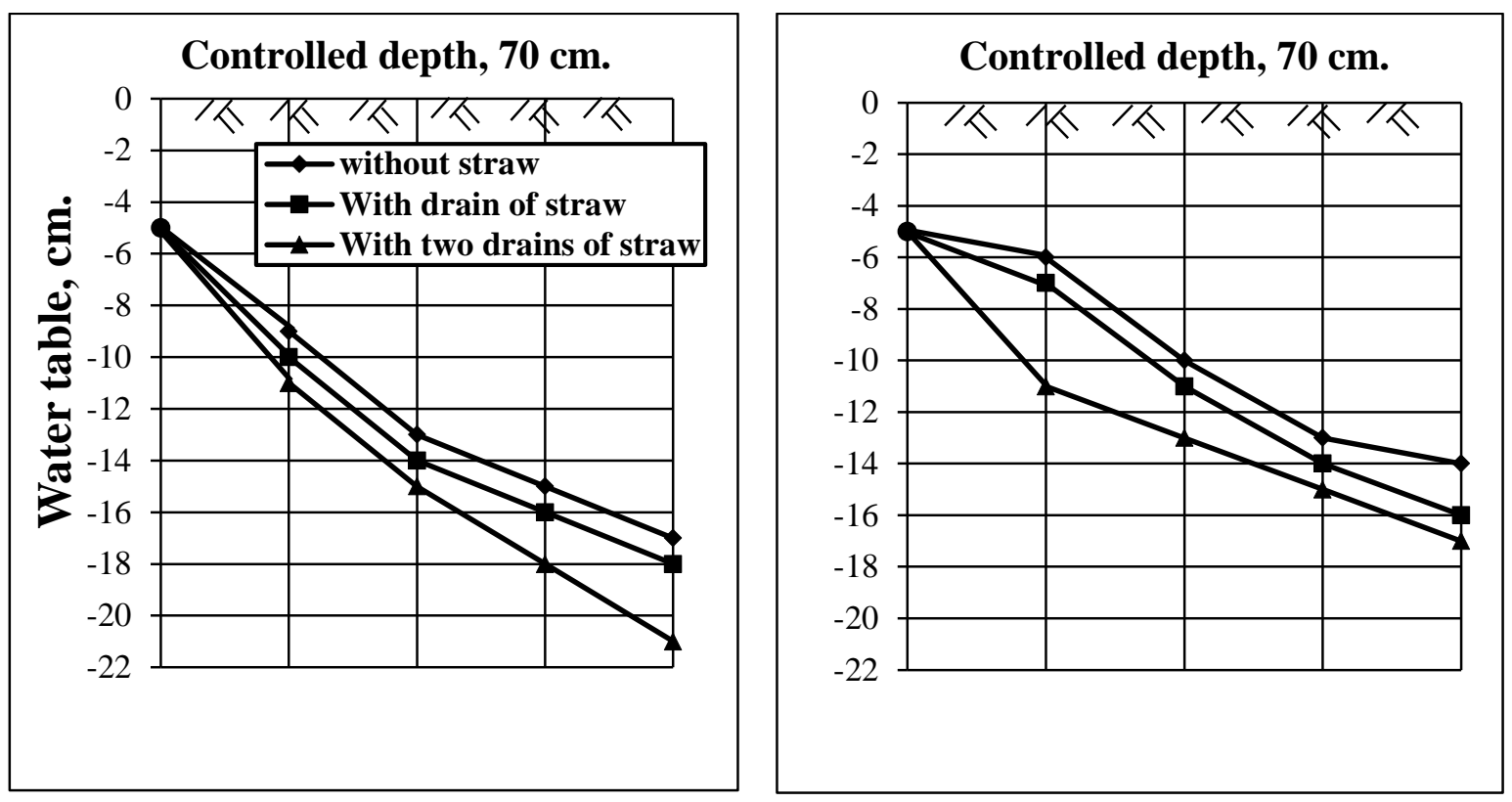

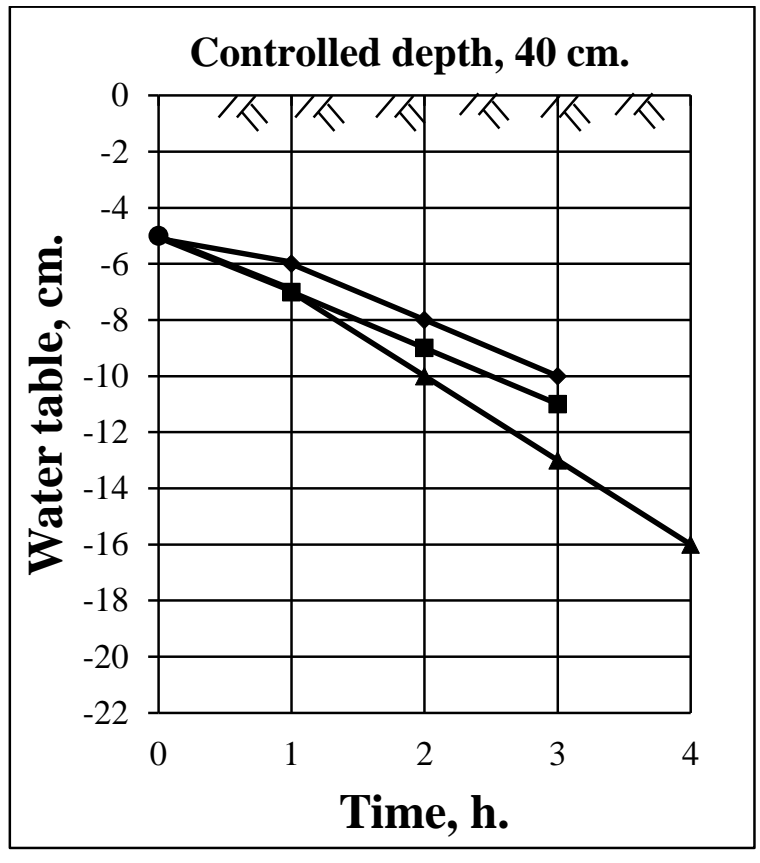

Distance from drain, $150 \mathrm{~cm}$.

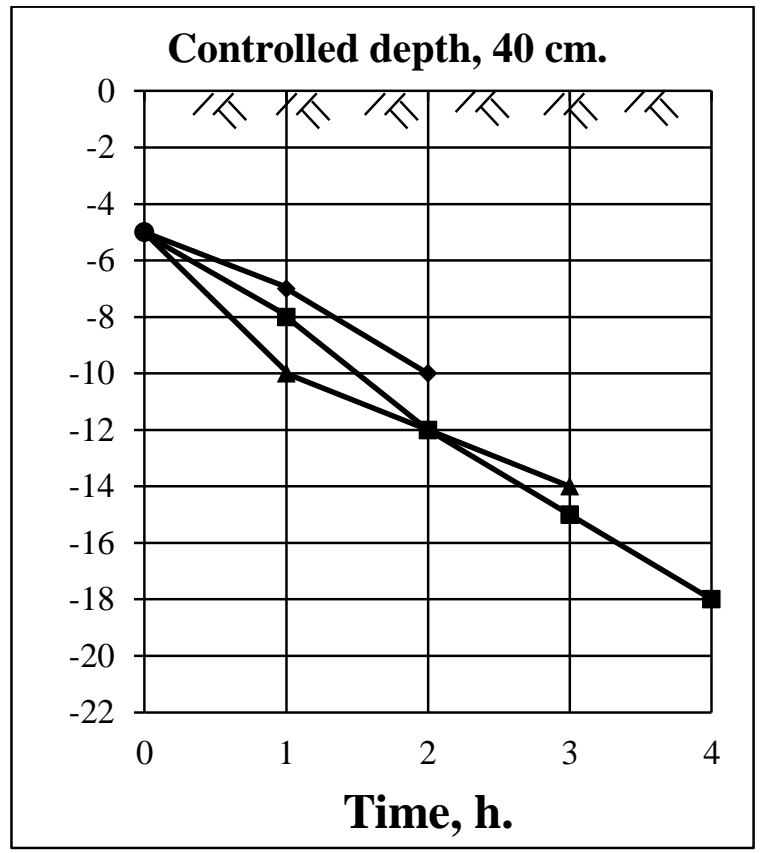

Distance from drain, $400 \mathrm{~cm}$.

Fig. 12: Variations in water table depth with time at 150 and $400 \mathrm{~cm}$ distances from drain with 70 and $40 \mathrm{~cm}$ controlled depths for silty clay soil without and with one and two drains of rice straw. 


\section{- The field experiment:}

1- Silty clay soil with drain of rice straw:

$\mathrm{h}=1.4 \mathrm{t} . \mathrm{k}(\mathrm{H} / \mathrm{s})^{-0.24}+0.11 \mathrm{H}$

2- Silty clay soil with two drains of rice straw:

$\mathrm{h}=5.31 \mathrm{t} . \mathrm{k}(\mathrm{H} / \mathrm{s})^{0.43}+0.04(\mathrm{~s} . \mathrm{H})^{0.5}$

\section{SUMMARY AND CONCLUSION}

This research aims at studying some engineering factors (drain-spacing, controlled depth in water table and soil properties) that control groundwater level to accommodate variant crops and periods in growing season.

So, two experiments carried out, namely: (1) a laboratory experiment (2) a field experiment.

\section{1- The laboratory experiment:}

Six treatments of soil were used, namely: sandy loam, sandy loam with drain of rice straw, sandy, sandy with drain of rice straw, clay loam with drain of rice straw and clay loam with two drains of rice straw. Three control depths were used for drainage outflow, namely: 20, 12 and $4 \mathrm{~cm}$ from soil surface. Two spaces for drains were used, namely: 30 and 80 $\mathrm{cm}$.

In general, results have demonstrated that:

1- Water table falling rate at mid-point between drains increases with the drainage depth and decreases with drain-spacing for both of soil with and without of rice straw.

2- Water table falling rate at mid-point between drains in sandy loam soil with drain of straw was much more than bare soil. For example, water table fall in $60 \mathrm{~min}$. with $30 \mathrm{~cm}$ drain-spacing and $20 \mathrm{~cm}$ drainage depth was $3.8 \mathrm{~cm}$ for sandy loam soil; and $9.8 \mathrm{~cm}$ for sandy loam soil with drain of straw.

3- Water table falling rate at mid-point between drains in sandy soil with drain of straw was less than bare soil. For example, water table fall in 30 min. with $30 \mathrm{~cm}$ drain-spacing and $20 \mathrm{~cm}$ drainage depth was $11 \mathrm{~cm}$ for sandy soil; and $8.7 \mathrm{~cm}$ for sandy soil with drain of straw.

4- Water table falling rate at mid-point between drains in clay loam soil with two drains of straw was more than one drain. For example, water 
table fall in $60 \mathrm{~min}$. with $30 \mathrm{~cm}$ drain-spacing and $20 \mathrm{~cm}$ drainage depth was $6.7 \mathrm{~cm}$ for clay loam soil with one drain of straw; and $9.1 \mathrm{~cm}$ for clay loam soil with two drains of straw.

\section{2- The field experiment:}

Three treatments of soil were used, namely: silty clay soil, silty clay soil with drain of rice straw and silty clay soil with two drains of rice straw. Two control depths were used for drainage outflow, namely: 70 and 40 $\mathrm{cm}$ from soil surface. Two spaces for drains were used, namely: 3 and $8 \mathrm{~m}$.

In general, results have demonstrated that:

1- Water table falling rate at mid-point between drains increases with the drainage depth and decreases with drain-spacing for both of soil with and without of rice straw.

2- Water table falling rate at mid-point between drains in silty clay soil with two drains of straw was more than one drain and one drain was more than bare soil.

Also, it has been got relations correlate between water table heights and time at different engineering designs for subsurface drainage system with different soils, with and without rice straw, by dimensional analysis.

Finally, it can be recommended by follows:

1- Using of water table control device decreases water table falling rate which makes shallow groundwater available for crop water use.

2- The addition of rice straw increases water table falling rate for all soils except sandy soil.

\section{REFERENCES}

Ayars, J. E.; E. W. Christen and J. W. Hornbuckle (2006). Controlled drainage for improved water management in arid regions irrigated agriculture. Agric. Water Manage. 86: 28-39.

Bonaiti, G. and M. Borin (2010). Efficiency of controlled drainage and subirrigation in reducing nitrogen losses from agricultural fields. Agric. Water Manage. 98: 343-352.

EL-Atfy, H. (2000). Modified drainage system for rice growing areas, a tool for water saving. Undersecretary of State for Minister's Office Affairs, Ministry of Water Res. Irri., Egypt. 
Evans, R. O. and R. W. Skaggs (2004). Development of controlled drainage as the best management practices in North Carolina. In: Cooke,R.A.(Ed.), Drainage VIII, Proc. $8^{\text {th }}$. I. Drainage Symp., Sacramento, C.A, U.S.A.,: 1-13.

Muirhead, W. A.; E. Humphreys; N. S. Jayawardane and J.L. Moll (1996). Shallow subsurface drainage in an irrigated vertisol with a perched water table. Agric. Water Manage. 30: 261-282.

Wahba, M.A.S. (2002). Multi criteria decision analysis for integrated water table management. Ph.D. Thsis, Irr., Hyd. Eng. Dept., Fac. Eng., Alex. U.: 120.

Yang, C. H.; T. K. Kim; J. H. Ryu; S. B. Lee; S. Kim; N. H. Baek; W. Y. Choi and S.J. Kim (2010). Effect of rice straw application on soil physic-chemical properties. World Congress of Soil Sci., Soil Solution for a Changing World. Brisbane. Australia. 13-15.

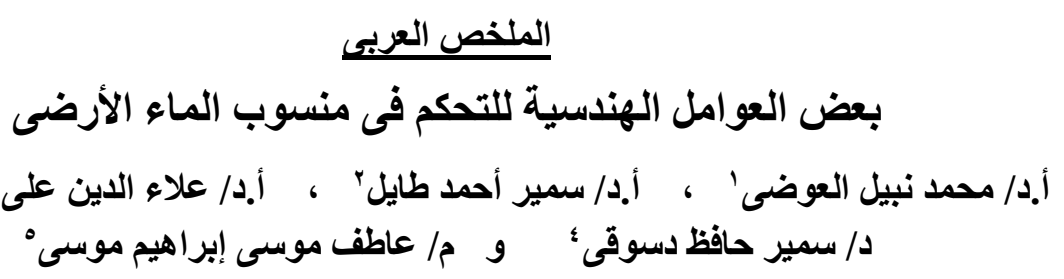

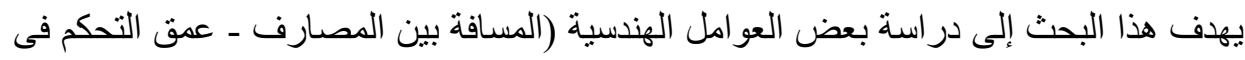

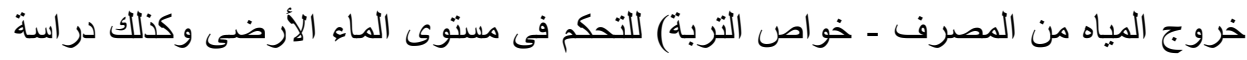
التغير ات فى عمق الماء الأرضى خلال أزمنه مختلفة. وذللك للوصول اللونى إلى أعماق المباه الأرضية التى تتاسب المحاصيل المختلفة ومر احل نمو ها. ولتحقيق هذه الأهداف تم إجر اء تجربتين ( ) تجربة معملية. (r) تجربة حقلية.

$$
\begin{aligned}
& \text { 1. أستاذ الهندسة الزراعية ـ كلية الزراعة - جامعة عين شمس. }
\end{aligned}
$$

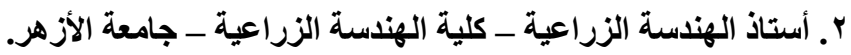

$$
\begin{aligned}
& \text { r. أستاذ الهندسة الزراعية ووكيل كلية الهندسة الزئة الزراعية - جامعة الأزهر. } \\
& \text { ؛. أستاذ مساعد بكلية الهندسة الزراعية - جامعة الأزهر. } \\
& \text { ه. مدرس مساعد بكلية الهندسة الزراعية - جامعة الأزهر. }
\end{aligned}
$$


* تالاً: التجربة المعلية:-

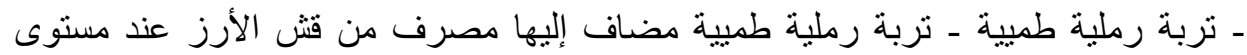

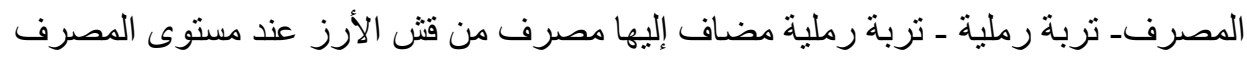

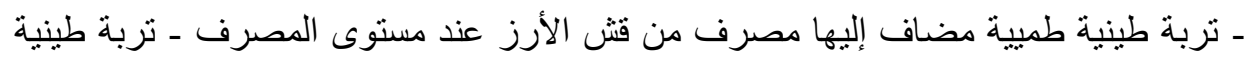

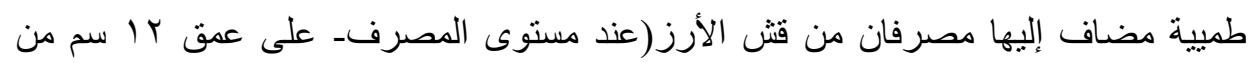
سطح التربة).

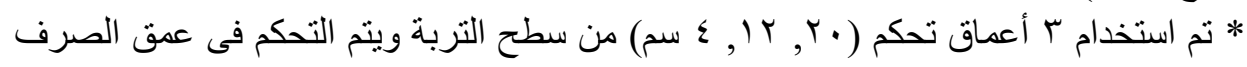

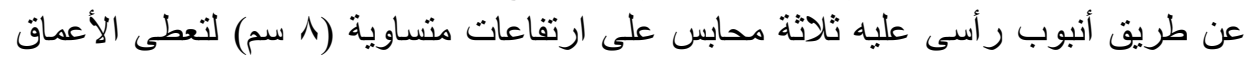

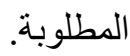
* تم استخدام مسافتان للمصارف: • بـ سم (بفتح المصرفين معاً أثناء الصرف) - . ـ سم (بفتح

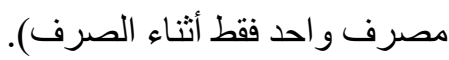
ولدراسة تأثير هذه المتغيرات نم قياس منسوب الماء الماء الأرضى خلال عملية الصرف فى أزمنة

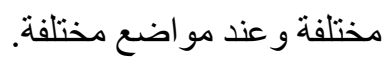
وتم إجراء التجارب فى معمل الرى بكلية الهندسة الزراعية- جامعة الأزهر للعام الجامعى r. أوضحت النتائج بصفة عامة أنه: اـ كلما زاد عمق الصرف زاد اد معدل هبوط مستوى المهاء الأرضى عند منتصف المسافة بين

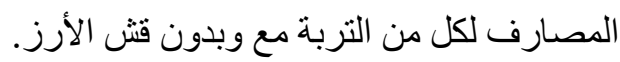

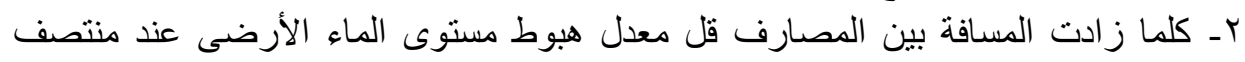

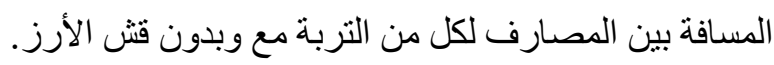

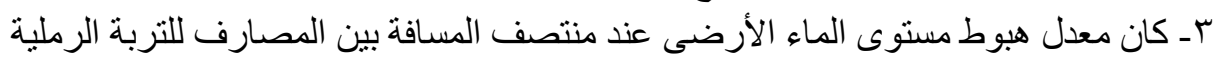

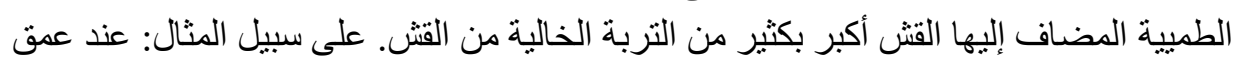

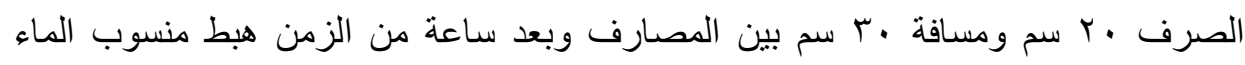
الأرضى إلى r, سم تحت سطح التربة للتربة بدون قش بينما هبط إلى

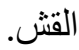

عـ كان معدل هبوط مستوى الماء الأرضى عند منتصف المسافة بين المصارف للتربة الرملية

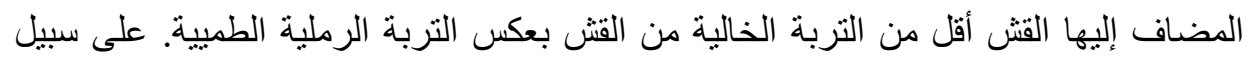

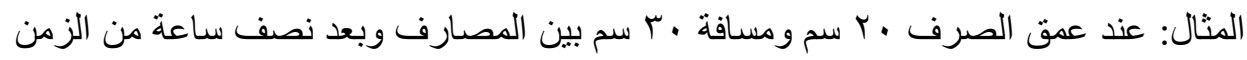

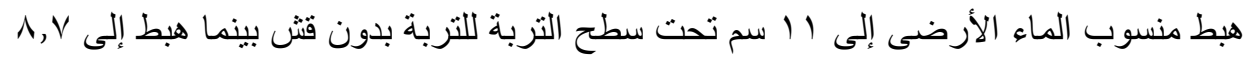

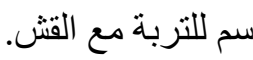
هـ كان معدل هبوط مستوى الماء الأرضى عند منتصف المسافة بين المصارف للتربة الطينية

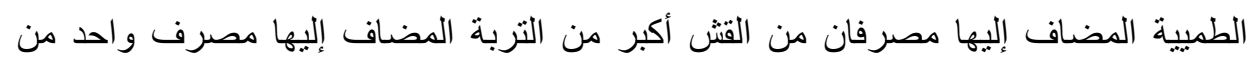

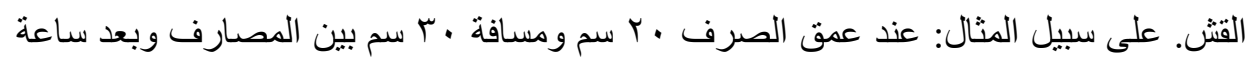




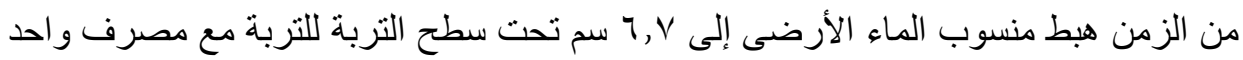

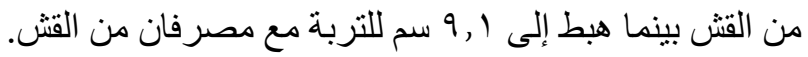

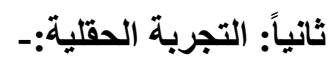

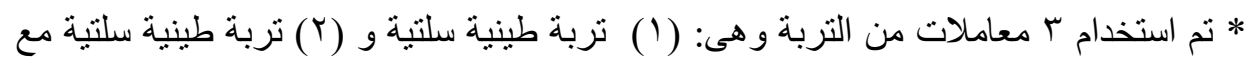

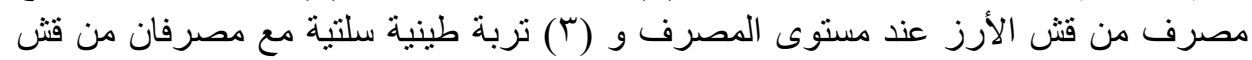

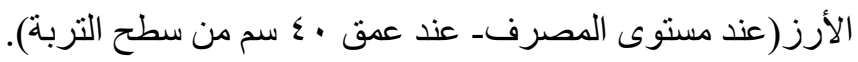

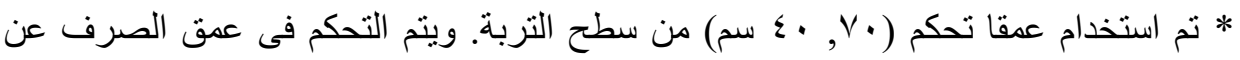

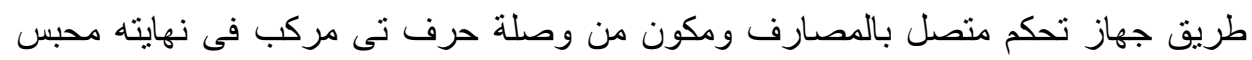

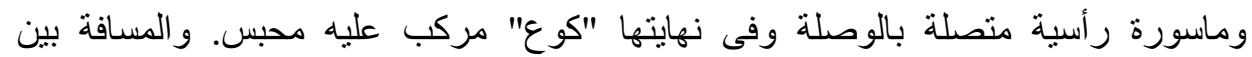

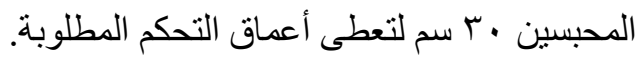

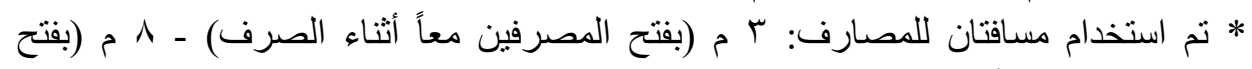

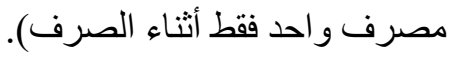
ولدراسة نأثير هذه المتغيرات تم قياس منسوب الماء الأرضى خلال عملية الصرف فى أزمنة مختلفة و عند مو اضع مختلفة. وتم إجر اء التجارب في مدينة بلبيس- محافظة الثرقية. وكانت النتائج بصفة عامة: اـ كلما زاد عمق الصرف زان زاد معدل هبوط مستوى الماء الأرضى عند منتصف المسافة بين

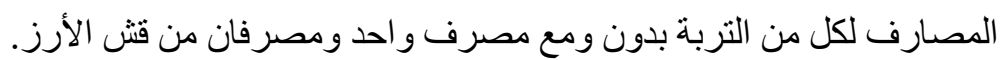

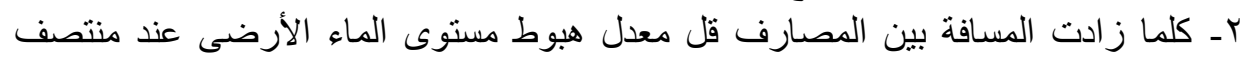

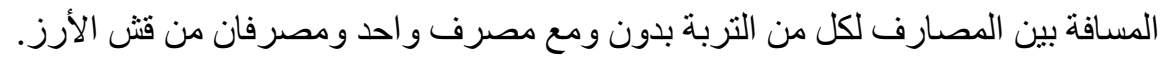

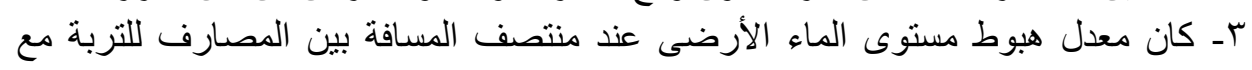

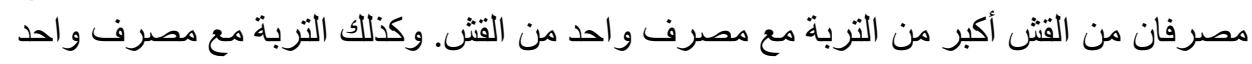

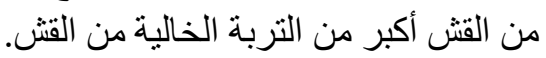

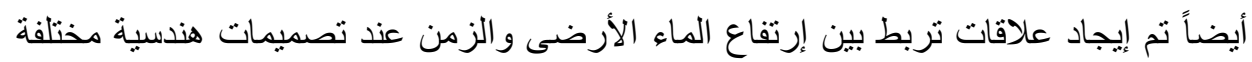

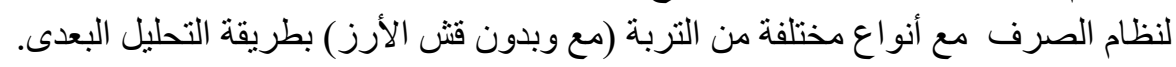

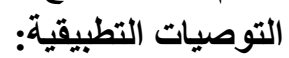

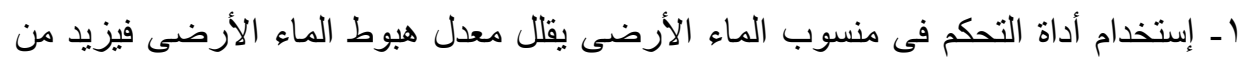
إستفادة النبات من المياه خاصة النباتات ذات التات الجذور الثعرية.

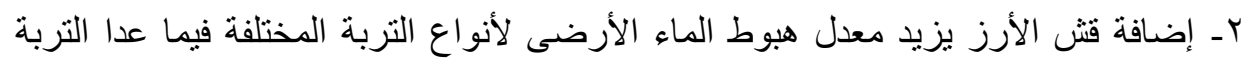

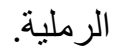

